\title{
The Role of Talent Management in the Relationships between Employee Engagement: A Study of GLCs
}

\author{
Afdzal Aizat Ramli ${ }^{1, *}$, Aerni Isa $^{1}$, Nur Lyana Baharin ${ }^{1}$, and Hazril Izwar Ibrahim² \\ ${ }^{1}$ Department of Management and Human Resources Universiti Tenaga Nasional, Kampus Sultan Haji Ahmad Shah, Bandar \\ Muadzam Shah, Pahang \\ ${ }^{2}$ School of Management, Universiti Sains Malaysia, Pulau Pinang, Malaysia
}

\begin{abstract}
Talent management practice is crucial in relating the potential talent. The GLCs need to have a potential talent in order to continue the value creation for business competitiveness. Moreover, talent that possesses high level of commitment and engagement will add value in the organization. This study aims to examine the relationship between talent management practices and employee engagement of employees at GLCs. The sample included 230 employees, which were selected randomly. For this study the method for data collection uses a structured questionnaire and were analyzed using partial least square. The hypothesis in this study is accepted whereby on the empirical evidences, it proves the relationship between talent management practices and employee engagement.
\end{abstract}

\section{Introduction}

In the contemporary world of work, to compete effectively, companies not only must recruit the top talent, but must also inspire and enable employee to apply their full capabilities to their work. GLICs are investment arms of the government that allocate government funds to the GLCs. In addition to having ownership in GLCs the Malaysian government also has an influence on the appointment of members of the board of directors and senior management positions. Many GLCs are rapidly growing, improving productivity and showing strong performance in their core businesses. GLCs are leading the way in performance in certain sectors such as banking, with Maybank and BCHB/CIMB showing significant improvement in their fundamentals. In addition to that, some GLCs have made waves in the international market, raising the profile of Malaysian businesses internationally, as well as raising industry standards.

To strive for success in the era of globalization, GLCs need to have a potential talent to continue the value creation for business competitiveness. Talent that possesses high level of commitment and engagement will add value in the organization. Contemporary organizations need employees, who are psychologically connected to their work; who are willing and able to invest themselves fully in their roles; who are proactive and committed to high quality performance standards. They need employees who feel energetic and dedicated, i.e., who are engaged with their work the applicable criteria that follow [1, 2] define an engaged employee as a worker who is fully involved in and enthusiastic about his or her work. Engagement was essentially defined as "an innate human desire to contribute something of value in workplace Employee engagement as a key to the retention of talent (one-of-a kind hire in 100 employees; [3] is an area in which the leads has been taken by practitioners [4-9]. Employee engagement is viewed as an important construct because it is has been linked to increasing the retention of top talent as an outcome of the talent management process for e.g. [10].

Talent management has now been identified as a critical enabler for the Government Transformation Programme (GTP), Economic Transformation Programme (ETP) and the 10th Malaysia Plan (20112015) to propel Malaysia towards the competitive status of a high income economy and achieve a vision 2020. It is time to tap the local talents to move forward. Malaysians need to synergize the strength to achieve the Strategic Reform Initiative of ETP in developing quality workforce and reducing dependency on foreign labour. GLCs should be given the opportunity to develop their own capacities and capabilities and consider sourcing talents with a global vision and culture.

Bureaucratic meddling, conflicting objectives, over-centralization of decision making and inadequate capitalization and the lack of managerial skills are also pressing problems for GLCs [11]. Directorship and senior managerial positions in GLCs where political patronage positions for retired military and high level civil servants, or for relatives and friends of powerful political leaders [12-13] According to [14] GLCs are facing issues on internal control, lacking in strategic direction resulting in poorer return on capital and shareholder value, lower productivity, higher gearing 
ratio, inefficient procurement handling, and ineffective performance management system.

Another issue that raised attention is the weak linkage between employee's performance and the reward scheme in GLCs [15]. The issues on ineffective performance management system thus creating job dissatisfaction. Among the employees which leads to changing of job attitudes, followed in the longer term by responses that are more retaliatory such as quitting [16]. When the evaluation process is not transparent, the outcome will be imbalance and it may give detrimental impact on employee engagement. Based on the finding by [17], it shows the unfairness in the performance management system and top management will always have the right to override the KPI points. Furthermore, the top management have the power to reduce or increase the total KPI points of the employees.

\subsection{Talent Management Practices.}

According to TalentCorp (Malaysia), talent management practices refer to a process of identifying, developing the potential talent. GLCs need potential talent to strive a success in an organization, as most of the GLCs expanding the operation internationally. Through the implication of talent management practices it helps the organization in retaining the potential talent to stay in the existing organization. Based on the study done by [18], there is insignificant relationship between talent management and employee engagement. Therefore this study will be more beneficial as empirical evidence is provided to prove the relationship between talent management practices and employee engagement. Employees that highly engaged contribute greater outcome, they are aware of business context and work closely with other colleagues at the workplace. Employee engagement is a vital for the organization in retention of top talent as being proposed by existing studies, for example by [10]. Furthermore, the key driver of employee engagement is the strong implementation of career development and this relates with talent management practices. As effective talent management practices can result in more engaged employees and lower turnover, it will bring forward positive outcome in enhancing the performance at GLCs [19].

\subsection{Employee Engagement.}

Employee engagement as a key to the retention of talent. Employee engagement has a substantial impact on employee productivity and talent retention. [20] see engagement as engaging employee into the strategic process which is different than the attitude and the behavior. Engagement is part of the "fair process" with explanation and clarity of expectations. Based on their findings, employees care about the justice of the process as much as they do the outcome itself. They claim that fair process affects people's attitudes and behaviors. In their model: Engagement is part of the fair process which is followed by trust and commitment (attitude). Then the employee voluntarily cooperates (behavior) and exceeds expectations (strategy execution). The authors define engagement as "involving individuals in the strategic decisions that affect them by asking for their input and allowing them to refute the merits of one another's idea and assumptions" (p.175).

\subsection{The Relationship between Talent Management Practice and Employee Engagement}

Employee engagement is the act of an employee being involved in, enthusiastic about, and satisfied with his or her work. Talent management practices and policies that demonstrate commitment to human result in more engaged employees and lower turnover [21]. The study done by [22] shown that there is a significant contribution between talent management practice (employee career development and rewards and recognition) and employee engagement. Based on the study done by [18], there is insignificant relationship between talent management and employee engagement. Therefore this study will be more beneficial as empirical evidence is provided to prove the relationship between talent management practices and employee engagement. Employees that highly engaged contribute greater outcome, they are aware of business context and work closely with other colleagues at the workplace. Employee engagement is a vital for the organization in retention of top talent as being proposed by existing studies, for example by [10]. Furthermore, the key driver of employee engagement is the strong implementation of career development and this relates with talent management practices. As effective talent management practices can result in more engaged employees and lower turnover, it will bring forward positive outcome in enhancing the performance at GLCs [23]. If employees feel they have the opportunity to expand their career, they are more likely to have positive feeling about the organization. In this context, career development for employees at GLCs is crucial, if the employees do not have the opportunity for career growth this lead to job dissatisfaction. Therefore, every organization needs to have a strong support on talent management practice which results in more engaged employees and lower turnover. The challenge today is not just retaining talented people, but fully engaging them, capturing their minds and hearts at each stage of their work life. The literature provides considerable support for the significant link between talent management practices and employee engagement. Therefore, the following hypothesis is proposed:

H1: There is a significant positive relationship between talent management practices and employee engagement. 


\section{Methodology}

A questionnaire survey was used to gather primary data for this study. Stratified random sampling technique is use to select the respondent for this study. The respondents for the study are drawn from GLCs employees in Malaysia. Questionnaire were reported using 5 likert scale ranging from (1) strongly agree to (5) strongly disagree. In this study, the questionnaire for talent management practices is adapted from research by [24] and [25] and employee engagement will be measured by 9-items Utrecht Work Engagement Scale (UWES-9) based from [26].

To investigate the research model, the statistical software application SmartPLS 3.0 [27] is used to compute the PLS path model. In evaluating and reporting the results, it is done by following recent guidelines for PLS-SEM given by [28] and [27]. Two step approaches were used, (1) confirmatory factor analysis, to confirm validity and reliability (2) structural equation model, to assess the path model [29]. IBM Statistical Package for Social Science (SPSS) version 22 was also used for importing data and to explain the descriptive statistics.

\section{Results and Analysis}

Table 1: Demographic

\begin{tabular}{|c|c|c|c|}
\hline Items & Characteristic & Frequency & Percentage \\
\hline Age & $\begin{array}{l}20 \text { and below } \\
21-38 \\
39-49 \\
50 \text { and above }\end{array}$ & $\begin{array}{l}4 \\
146 \\
44 \\
19\end{array}$ & $\begin{array}{l}1.9 \\
68.5 \\
20.7 \\
8.9\end{array}$ \\
\hline Gender & $\begin{array}{l}\text { Male } \\
\text { Female }\end{array}$ & $\begin{array}{l}90 \\
123 \\
\end{array}$ & $\begin{array}{l}42.3 \\
57.7 \\
\end{array}$ \\
\hline $\begin{array}{l}\text { Marital } \\
\text { Status }\end{array}$ & $\begin{array}{l}\text { Married } \\
\text { Single }\end{array}$ & $\begin{array}{l}131 \\
78\end{array}$ & $\begin{array}{l}61.5 \\
36.6\end{array}$ \\
\hline Education & $\begin{array}{l}\text { Secondary } \\
\text { School } \\
\text { Diploma } \\
\text { Degree } \\
\text { Master } \\
\text { Ph.D. }\end{array}$ & $\begin{array}{l}8 \\
32 \\
136 \\
35 \\
1\end{array}$ & $\begin{array}{l}3.8 \\
15.0 \\
63.8 \\
16.4 \\
.5\end{array}$ \\
\hline Service & $\begin{array}{l}\text { Less than } 5 \\
\text { years } \\
6-10 \text { years } \\
11-15 \text { years } \\
\text { Above } 16 \text { years }\end{array}$ & $\begin{array}{l}70 \\
62 \\
44 \\
35\end{array}$ & $\begin{array}{l}32.9 \\
29.1 \\
20.7 \\
16.4\end{array}$ \\
\hline Salary & $\begin{array}{l}\text { RM2,000 and } \\
\text { below } \\
\text { RM2,001.00 - } \\
\text { RM 4,000.00 } \\
\text { RM4,001.00 - } \\
\text { RM 6,000.00 } \\
\text { RM 6,001.00 } \\
\text { and above }\end{array}$ & $\begin{array}{l}44 \\
46 \\
47 \\
74\end{array}$ & $\begin{array}{l}20.7 \\
21.6 \\
22.1 \\
34.7\end{array}$ \\
\hline
\end{tabular}

Table 1 above are the demographic profile of the respondent. The respondents aged between 21 and 38 years constituted the biggest category (at 68.5\%). Those aged between 39 to 49 years constituted $20.7 \%$ of the sample. The respondents aged between 40 and 49 years constituted the remaining $18.4 \%$ of the sample.
It can be concluded from the above table that majority $(57.7 \%)$ of the respondents for this study are female. The remaining $14.6 \%$ of the respondents are males. At the same time majority $(61.5 \%)$ of the respondents were married. The remaining $36.6 \%$ of the respondents are single. Maximum numbers of respondents (63.8\%) are degree holder, $16.4 \%$ of the respondents are master holders, and $15.0 \%$ of the respondents are diploma holder. Majority of the respondents $(32.9 \%)$ are having less than 5 years of experience. As for the salary, it could be conclude that, most of the respondent salary are at the range of RM 6001.00 and above (34.7\%).

\subsection{Measurement Model}

\subsubsection{Convergent validity}

In analyzing the measurement model convergent validity need to be assess. Convergent validity is the degree to which that constructs that are expected to be related are, in fact, related. For convergent validity, it will be verified through average variance extracted (AVE) [30]. AVE measure the amount of variance captured by a construct by calculating the ratio of the amount of the variance captured by the construct and the measurement variance. Convergent validity is adequate when constructs have an AVE of at least 0.5 with factor loading of each item at $\geq 0.6[31,32]$. Base from table 1 above, all constructs statistically achieved the AVE $>0.5$, where talent management practice with AVE 0.582 and employee engagement with 0.773. All factor loading are also range from 0.651 to 0.905 which is as recommended by [31]. Comply with the aforementioned scholar's convergent validity of each dimension inspection standards, the various aspects of this study have convergent validity.

\subsubsection{Discriminant validity}

Discriminant validity is the degree to which item distinguish among the construct [33]. Discriminant validity was measured by evaluating the correlations between constructs and the square root of AVE for that construct [31]. Besides that, the square root of AVE must be higher than the correlations values in the row or column. [34]. Table 2 shows the discriminant validity of this study. Therefore, the measurement model is accepted as it fits all the criteria of convergent and discriminant validity.

\subsubsection{Reliability analysis}

Reliability analysis was done to determine the reliability of the questionnaire. As for this study reliability will be assess through (1) internal consistency and (2) cronbach's alpha. To measure internal consistency the composite reliability were tested. As recommended [34] for composite reliability, all the items must be more than 0.70 as the minimum value is 0.70 . From table 2 we can see that all value for composite reliability for all the items are more than 
0.70. The value of composite reliability for items of talent management practice is 0.967 , and value for employee engagement items is 0.968 . Therefore it could be concluded that high level of internal consistency reliability have been demonstrated among latent variables. As for the cronbach's alpha, the suggested value for cronbach's alpha is above 0.6 [35]. Based on the result, all the cronbach's alpha value for each construct are above 0.6 where the value for talent management practice are 0.964 and employee engagement are 0.963. Align with the composite reliability, all the construct are exceed the suggested value and it's showed all the measurement are reliable.

\subsubsection{Structural model}

After reliability and validity testing is completed, next is the path for the PLS model coefficient test and predict estimated structural model analysis. Consistent with [36] bootstrapping (500 sample) was used to generate t-statistics. This allows us to access the statistical significance of the path coefficients. The use of the $t$-value to estimate the $p$-value, to test the significance of coefficient the carried out to determine the hypothesis whether was established [37]. Examining the path coefficient value, a researcher is able to know the strength of the relationship between variable [38]. Table 4 and Fig. 1 show the result of the structural model from the PLS output.

Based on the result, hypothesis which were proposed were accepted as the $t$-value is significant at $\mathrm{p}<0.01$. In structural model, $\mathrm{R}^{2}$ of the variables could expresses the proportion of variance in the independent variables (talent management practice) explained by the structural relationships for the dependent variable (employee engagement). Based on the result in table 4, $\mathrm{R}^{2}$ was found to be 0.614 which indicates that the PLS regression model can explain $61.4 \%$ of total variance in employee engagement. It is similar with the assessment suggested by [39] 0.26 substantial, 0.13 moderate and 0.02 weak. Thus, in this study $\mathrm{R}^{2}$ here is considered substantial. Another criterion to assess the quality of the model is using the blindfolding procedure to generate the cross-validate communality and cross-validated redundancy, where $\mathrm{Q}^{2}$ values will be calculated. According to [31] the model will have predictive quality if the cross-redundancy value was found to be more than 0 , otherwise the predictive relevance of the model cannot be concluded. From the results in table 4 , the obtained cross validated redundancy was found to be 0.417 . This result supports the claim that the model has an adequate prediction quality.

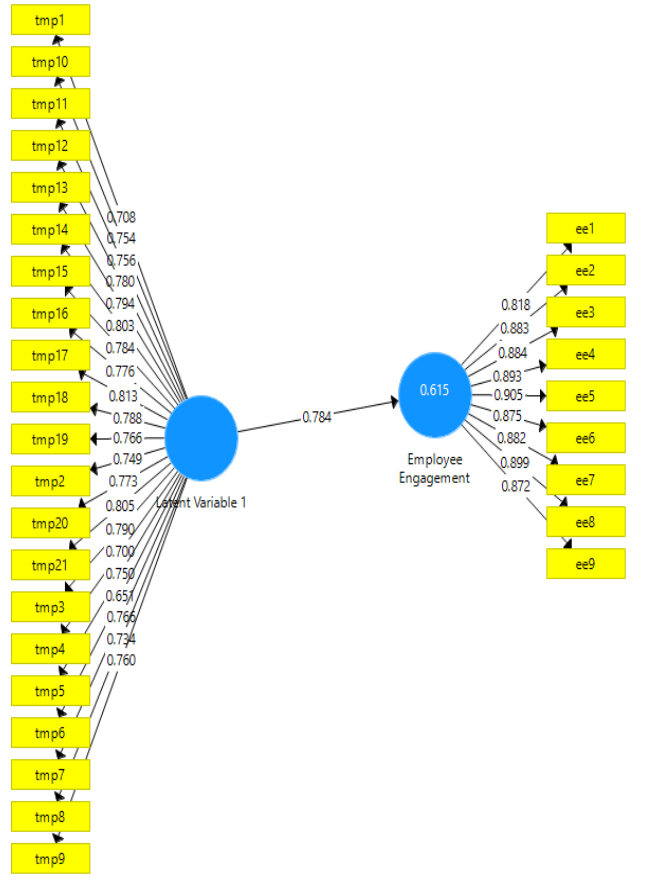

Fig. 1. structural model

Table 2: Result of measurement model

\begin{tabular}{|c|c|c|c|c|c|}
\hline $\begin{array}{c}\text { Constru } \\
\text { ct }\end{array}$ & $\begin{array}{c}\text { Measure } \\
\text { ment } \\
\text { items }\end{array}$ & $\begin{array}{c}\text { Loadi } \\
\text { ngs }\end{array}$ & $\begin{array}{l}\text { AV } \\
\text { E }\end{array}$ & CR & $\begin{array}{c}\text { Cornbac } \\
\text { h's } \\
\text { Alpha }\end{array}$ \\
\hline $\begin{array}{l}\text { Talent } \\
\text { manage } \\
\text { ment } \\
\text { practice }\end{array}$ & $\begin{array}{l}\text { TMP1 } \\
\text { TMP2 } \\
\text { TMP3 } \\
\text { TMP4 } \\
\text { TMP5 } \\
\text { TMP6 } \\
\text { TMP7 } \\
\text { TMP8 } \\
\text { TMP9 } \\
\text { TMP10 } \\
\text { TMP11 } \\
\text { TMP12 } \\
\text { TMP13 } \\
\text { TMP14 } \\
\text { TMP15 } \\
\text { TMP16 } \\
\text { TMP17 } \\
\text { TMP18 } \\
\text { TMP19 } \\
\text { TMP20 } \\
\text { TMP21 }\end{array}$ & $\begin{array}{l}0.708 \\
0.749 \\
0.79 \\
0.700 \\
0.750 \\
0.651 \\
0.766 \\
0.734 \\
0.760 \\
0.754 \\
0.756 \\
0.780 \\
0.794 \\
0.803 \\
0.784 \\
0.776 \\
0.813 \\
0.788 \\
0.766 \\
0.773 \\
0.805\end{array}$ & $\begin{array}{l}0.5 \\
82\end{array}$ & $\begin{array}{l}0.9 \\
67\end{array}$ & 0.964 \\
\hline $\begin{array}{l}\text { Employe } \\
\mathrm{e} \\
\text { engagem } \\
\text { ent }\end{array}$ & $\begin{array}{l}\text { EE1 } \\
\text { EE2 } \\
\text { EE3 } \\
\text { EE4 } \\
\text { EE5 } \\
\text { EE6 } \\
\text { EE7 } \\
\text { EE8 } \\
\text { EE9 }\end{array}$ & $\begin{array}{l}0.818 \\
0.883 \\
0.884 \\
0.893 \\
0.905 \\
0.875 \\
0.882 \\
0.899 \\
0.872\end{array}$ & $\begin{array}{l}0.7 \\
73\end{array}$ & $\begin{array}{l}0.9 \\
68\end{array}$ & 0.963 \\
\hline
\end{tabular}


Table 3: Discriminant validity

\begin{tabular}{|c|c|c|}
\hline Construct & $\# 1$ & $\# 2$ \\
\hline $\begin{array}{l}\text { \#1 Talent management } \\
\text { practice }\end{array}$ & 0.784 & \\
\hline \#2 Employee engagement & 0.763 & 0.879 \\
\hline
\end{tabular}

Note: Values on the diagonal (bolded) are square root of the AVE while the off-diagonals are correlations

Table 4: Summary of structural model

\begin{tabular}{|l|l|l|l|l|l|l|}
\hline $\begin{array}{l}\text { Hypothesi } \\
\mathrm{s}\end{array}$ & $\begin{array}{l}\text { Stand } \\
\text { ard } \\
\text { data }\end{array}$ & $\begin{array}{l}\text { Standa } \\
\text { rd } \\
\text { error }\end{array}$ & t-value & $\begin{array}{l}\text { Decisio } \\
\mathrm{n}\end{array}$ & $\mathrm{R}^{2}$ & $\mathrm{Q}^{2}$ \\
\hline $\begin{array}{l}\text { Talent } \\
\text { managem } \\
\text { ent } \\
\text { practice - } \\
\begin{array}{l}\text { Employee } \\
\text { engageme } \\
\text { nt }\end{array}\end{array}$ & 0.784 & 0.786 & $\begin{array}{l}24.883^{*} \\
*\end{array}$ & $\begin{array}{l}\text { Accepte } \\
\mathrm{d}\end{array}$ & 0.61 & 0.43 \\
& & & & 7 & \\
\hline
\end{tabular}

\section{Conclusion}

It has been empirically shown the bigger the $\mathrm{R}^{2}$, the higher the predictive power of the model. The proposed model shows that $61.4 \%$ of the proportion in variance. This finding concurs with previous study by $[40,22]$. Therefore this study would be beneficial for GLCs as there are limitations on empirical evidence on the study of talent management. Based on the empirical evidences in this study it proves the positive relationship between talent management practices and employee engagement. As Malaysia aspires to transform into a developed and more competitive economy by 2020 , talent will play a crucial role in order to strive for success and to sustain strong economic growth. In order for the GLCs to retain the talent it is important for the organization to focus on nurturing and developing talent of the human capital in GLCs.

The authors also acknowledge that the study is somewhat limited in size and scope in that we only test on few GLCs. The respondents were drawn from only five GLCs, while different types of GLCs may report different results if surveyed.

\section{References}

1. G. Bakker, A.B., M. P. Leiter, Work engagement: $A$ handbook of essential theory and research (New York, 2010)

2. T. Tritch, Gall. Man. J., (2003)

3. E. K. Glen, C. H. Elaine, L. S. Mathew, ACAD MANAGE J 49(5), 1031-1057 (2006)

4. A. Parsley, Man. Ser., 50 (1), 10-11 (2006)
5. R. Baumruk, B. Gorman, R. E. Gorman, J. Ingham, "Why Managers are Crucial to Increasing Engagement" (2006)

6. C. Woodruffe, Brit. J. Admin. Man., 50, 28-9 (2005)

7. Gall. Man. J., http://gmj.gallup.com (2006)

8. M. Bennett, A. Bell, Leadership \& Talent in Asia (Wiley, Singapore, 2004)

9. Hay Group, Inc. Reward program implementation - missed opportunities. www.haygroup.com (2002)

10. J. Bhatnagar, Talent Management Strategy of Employee Engagement in Indian ITES (2007)

11. M. M. Shirley, P. W. Patrick, Public versus private ownership, 2420. World Bank Publications, Strategic HR Review 5(2), 24-7 (2000)

12. W. L. Megginson, R. C. Nash, M. V. Randenborgh, J. Fin., 49(2), 403-452 (1994)

13. A. R. Vining, E. B. Anthony, Pub. Choice, 73(2), 205-239 (1992)

14. Y. Azman, An Overview of a Nation Building Institution http://tkr.khazanah.com.my/nationbuilding-institution/ (2004)

15. A. B. Abdullah, "Culture of High Performance for GLC's", Keynote Address Presented at the Seminar on Culture of High Performance for GLCs"

www.pmo.gov.my/WebNotesApp/ABDULLAH.n sf/ (Theatrette, Ministry of Finance, Putrajaya, 2004)

16. E. Vigoda, J. Voc. Behav., 57, 326-347 (2000)

17. R. Abu Bakar, Understanding Factors Influencing Employee Engagement: A Study of the Financial Sector in Malaysia. Doctoral Thesis. (School of Management, RMIT University, 2013)

18. K. Rooper, The relationship between employees' perceptions of talent management practices and levels of engagement: A Botswana organisation case study, (Master Thesis, 2009)

19. A. Isa, H. I. Ibrahim, Int. J. Bus., Eco. L., 4(1), (2014)

20. W. C. Kim, R. Mauborgne, Blue Ocean Strategy (Boston, Massachusetts: Harvard Business School Publishing Corporation, 2005)

21. B. Lockwood, The political economy of decentralization (Edward Elgar Publishing, 2006)

22. N. E. Alias, H. Mat Noh, R. Hassan, J. Hum. Res. Man. L. Stud., 2(2), 227-242 (2014)

23. A. Isa, H. I. Ibrahim, Int. J. Bus., Eco. L., 4(1), (2014)

24. P. Bernsen, M. Segers, H. Tillema, Int. J. Hum. Res. Dev. Man., 9(4), 358-373 (2009)

25. H. Baert, J. W. Learn. (2010)

26. B. Schaufeli, W. H. Macey, K. M. Barbera, Edu. Psycho. Mea., 66 (4), 701-716 (2006) 
27. Hair, Ringle, Sarstedt, J. Market. T. Pra., 19(2), 139-152 (2011)

28. W. W. Chin, B. L. Marcolin, P. R. Newsted, Info. Sys. Res, 14(2), 189-217 (2003)

29. J. C. Anderson, W. G. David,"Structural equation modeling in practice: A review and recommended two-step approach." Psychological bulletin 103, no. 3, 411 (1988)

30. Sabri Ahmad, Zulkurnain, N. N. A., Khairushalimi, \& Izzati, F., (2016)

31. Fornell, Claes, David F. Larcker, J. Market. Res., 382-388, (1981)

32. J. F. Hair, E. Rolph, B. J. B. Anderson, C. B. Wiiliam, Multivariate data analysis: A global perspective (NJ: Pearson, 2010)

33. C.M.K. Cheung, M.K.O. Lee, 4(1), 161-172 (2010)

34. D. Compeau, C. A. Higgins, S. Huff, MIS quarterly, 145-158 (1999)

35. J. C. Nunnally, I. Bernstein, Psycho. Theo., 3(1), 248-292 (1994)

36. J. Henseler, C. M. Ringle, R. R. Sinkovics, Adv. Int. Market., 20(1), 277-319 (2009)

37. L. L. Bove, S. J. Pervan, S. E. Beatty, E. Shiu, J. Bus. Res, 62(7), 698-705 (2009)

38. A. Martinez-Ruiz, T. Aluja-Banet, Stat. J., 7(3), 265-290 (2009)

39. Cohen, Stat. Pwr. Ana, (1988)

40. M. Dass, S. Muthaly, J. Annakis, J. Cont. Iss. Bus. Gov., 21(1), (2015) 